\title{
Nepal and India Hydropower Cooperation: A Beneficial Peaceful Diplomacy
}

\author{
Eby Johny \\ United Nations Educational, Scientific, and Cultural Organization Madanjeet Singh Institute for South Asia Regional Cooperation, \\ Pondicherry University, Pondicherry, India
}

Email address:

Ebyjohnychrist @gmail.com

\section{To cite this article:}

Eby Johny. Nepal and India Hydropower Cooperation: A Beneficial Peaceful Diplomacy. International and Public Affairs. Vol. 5, No. 1, 2021, pp. 19-22. doi: 10.11648/j.ipa.20210501.14

Received: February 3, 2021; Accepted: March 18, 2021; Published: April 26, 2021

\begin{abstract}
India and Nepal are having very cordial relations, not only from now but for a long time back in History. The geographical location of Nepal has made it very much important for India. China has already made effective incursions into neighboring countries of India. China is also supplying large number of arms to Nepal. Although Nepal Politicians are aware of the dangers of receiving Chinese aid, China is making irrefutable promises, both financially and otherwise. India, which is economically and politically backward compared to China, cannot provide an alternative. When the border dispute broke out, many countries took a stand against China and informed India but unfortunately Nepal was not stand with India. Countries such as Germany, France, Britain and Australia, which are seeking to increase their influence in the Indo-Pacific region, have also extended a helping hand to India. Even so, the only two countries that can directly confront China economically and politically are the United States and Russia. India can make policy decisions on the Chinese issue only in the face of a number of issues, including the Chinese invasion of the Indian subcontinent, the growing Chinese influence in neighboring countries, the Sino-Russian alliance, and the antagonism of China and Russia.
\end{abstract}

Keywords: Nepal India Relation, Hydropower, Chinese Influence, Diplomacy, Political and Economic Benefits

\section{Introduction}

There are multiple factors behind good relationships between countries of any region in the world. To provide economic, political, or other benefits in expectation of gaining the same is the main motive of any country behind such strategic relationships. Energy is one of the primary sources of income of every country which provides economic stability to the nation. It is one of such factors that play a prominent role in shaping the terms between countries and bringing coordination in a region. Drastically increasing demand, high cost, and impact on climate due to increase carbon emission is forcing all countries to go for renewable or alternative sources of energy rather than conventional resources. It can also bring more trust and prosperity in the region if countries can give more preference to their neighbor for such energy trading rather than importing it from outside countries at a higher cost. Alternative Energy Resource Trading is like a bridge that can joint economic development, environment protection, and regional co-operation.
South Asia is one of the biggest regions of the world which has an area of about 5.1 million $\mathrm{km}^{2}$ with a population of 1.7 billion. Nepal is a nation that has the potential $40000 \mathrm{MW}$ of hydropower due to Himalayan Rivers [1]. But so far it has developed only $600 \mathrm{MW}$ of hydropower energy. It is an irony that this nation is not using its resources even though the biggest market is available in its neighborhood which is in need of electricity.

The country is having mostly small run- of- river hydropower projects due to the presence of fast-flowing rivers. Due to the freezing of such Himalayan rivers in the dry season, all the hydroelectricity plants become unworkable which brings huge energy scarcity in the country [2]. It compels the country to purchase electricity from India which ultimately increases its economic deficit. Big load shedding is unavoidable for Nepal Electricity Authority.

Lack of long instability has become an obstacle for taking strong decisions. Poor infrastructures, unavailability of technology, and fund dependency are some other reasons [3]. India is one of the largest countries in South Asia in terms of 
area as well as population. This increasing population is directly proportional to the growing energy demand which is leading to enhancing energy import of the country. Growing imported fossil fuels is another fact of concern that causes economic deficit as well as environmental depletion [4]. While such conventional energy resources are very vulnerable in terms of prices and at the same time, it gives extra concern due to its environmental degradation nature. Though India is having huge renewable energy potential still it is suffering from high demand and less supply problem in terms of electricity and several other resources are being used to fulfill the demand but still, India needs to have better trading with its neighbor, especially in terms of renewable energy trading because it will not only fulfill its power demand but it will also reduce its environmental protection burden [5].

\section{Peaceful Cooperation}

India and Nepal are having very cordial relations, not only from now but for a long time back in History. The geographical location of Nepal has made it very much important for India. Religious, ethnic similarities also made both the countries feel similar to each other. Similarly, India, the biggest country in South Asia plays a very important role due to its geographical location which makes her an immediate neighbor of nine countries, huge human energy resources, market potential, etc [6]. Despite having huge hydropower potential, Nepal is unable to make use of it due to several reasons.

On the other hand, India, which is also seeking a renewable power supply, has shown her interest in hydropower trading with Nepal. Kosi, Gandak, and Mahakali hydropower projects are some of the main examples of this fact. Since both the countries have experienced common problems like electricity scarcity, flood, and drought-like situation, hence both have realized the importance of each other. Nepal's untapped hydropower resources and India's engineering and investment can give lots of benefits to both countries [7]. To find the answer to the question of whether both the countries can enhance their trade-in hydropower and how far it would be the right decision for both the countries in order to maintain their growth, it can be concluded that various parameters are indicating that both the countries are in need of power and both of them can fulfill their need by working with each other. Since the number of electricity consumers and electricity consumption per capita is increasing every year in both countries hence both are in need of maintaining the demand and supply balance [8].

In this way increase in hydropower, trading has become an essential need for both countries. Though some of the impacts and challenges of hydropower plants cannot be denied but by taking proper measures and by introducing the latest technology, sustainable development can be brought in both countries [9]. Similarly, social issues that occur during the hydropower projects like land acquisition, urban migration; poor health, and sanitation problems can be handled very efficiently by implementing and practicing governmental policies properly. More participation of people in the decisionmaking process will help in the fast and uninterrupted completion of projects. The type of cooperation, both the countries are showing in the regional level under South Asian Regional Cooperation (SAARC), similar cooperation is needed from both the side in hydropower. sector. Just like Bhutan, even Nepal can use its vast hydropower potential and make its an economy more strong [10]. To reach such a strong, stable relationship, political will, and grass route level cooperation is required between both countries.

It is a mutual benefit for both the countries where Nepal can fulfill its domestic need by involving herself in hydropower exploration and for India, this could be a better investment where economic benefit can be gain, electricity can be supplied to states like Bihar and Uttar Pradesh which are suffering from electricity shortage and duty of reducing greenhouse gases can also be completed. All the International Environmental summits are showing the continuous degrading picture of the environment. An increase in greenhouse gases is also responsible for global warming which is not only resulting in melting the glacier but season imbalance, natural disasters, and the threat of submerging for the other island countries, etc. In order to bring the cumulative solution, joint efforts are decided during such International summits [11]. In these summits, developing countries are asked to reduce their carbon emission to protect the environment.

In this case, hydropower is a boon for the energy need of both India and Nepal. It will definitely give a duel benefit of fulfilling the energy demand of both the countries, along with the inability of bringing development with respect to environmental protection [12]. It will help both the countries to fulfill the target of reducing dependency on conventional fuel sources and shift towards renewable resources. It will definitely give a positive impression of both the country, not only inside the South Asian region but it will also be appreciated in the whole world due to tackling carbon emission issue by bilateral approach. Though high installation charges cannot be denied as the additional burden on the economy of the countries in terms of the near future, the output will be very much in favor of both countries.

\subsection{Political Context}

Since the political will is the prime need for any bilateral agreements, there should be efforts from both countries to initiate and promote ideas in hydropower. Usually, the opposition party of any country has a tendency of discouraging every decision taken by the ruling party due to their political motives which ultimately leads to unnecessary delay in the new initiative.

Proper electricity supply is also a part of the national interest of both India and Nepal, hence more agreements could be signed and implement between both countries. Unnecessary delay in decision making and information of new agreements needs to be reduced. 


\subsection{Economic Context}

Nepal is using only $1 \%$ of its hydropower capacity and every year Nepal Electricity Authority (NEA) is having revenue loss due to the closing of power generation during the dry season, hence Nepal should prepare a development plan with help of India to enhance total hydropower installed capacity [13]. By considering this plan as a big target 'to be achieved', hydropower potential could be explored.

Private companies need to be motivated to take part in the hydropower field and work in this area. The government is needed to give more favorable conditions for private players so that they will get motivated to take interest in the hydropower sector.

Sometimes lots of money gets wasted due to local people's agitation during the construction of the project, hence more beneficial policies need to be framed along with more participation of local people so that the extra cost and delay of the project could be reduced. More hydropower projects should be initiated, especially focusing on Nepal's electricity problem during the dry season. Instead of investing in large hydropower projects, medium and small projects should be given preference as it would not give that much strain to the economy due to its less financial requirement as compare to the large projects. As it is observed that Indian states bordering Nepal are also having acute electricity shortage, hence more investment and joint initiative should be done to get excessive electricity from Nepal during summer and to give electricity to Nepal during winter. Since the population is growing, hence number of consumers cannot be reduced through consumption per capita can be reduced. Hence more steps should be taken to reduce electricity consumption per capita. It could be done by working in multiple areas like spreading awareness regarding excessive electricity consumption, encouraging people to opt for renewable energy resources.

\subsection{Environment}

Environmental Impact Assessment (EIA) should be made more balanced where positive as well negative effects of hydropower should be analyzed [14]. A joint assessment by some think tank or any organization should be done which will not only deal with the problems but will give a feasible solution of those problems. In order to reduce the dependency on conventional energy resources, a long-term goal can be set to shift from conventional to renewable energy [15]. It will bring sustainable development in both countries.

\subsection{Education}

More investment in Research and Development in the technology of hydropower plants needs to be done. Scientists and scholars should get encouraged to work in this area so that more efficient and cost-effective solutions can be done [16]. Awareness from grass root level regarding the importance of hydropower should be spread. It could be done, by establishing a working team consisting of people from the local community so that much improvement can be seen. More educational institutions that deal with hydropower potential and its exploration, needs to be established in both countries [17]. A joint research Centre should be established which can include scholars from both countries to work jointly in order to study each and every aspect of the hydropower projects, its challenges, and possibilities. Media needs to be encouraged to focus so that every angle of this issue can be reached to every household and people will be more aware of Environment protection [18]. It will also help policymakers to bring improvements in existing acts and agreement.

\section{Conclusion}

Both the countries can enhance their friendship in national security and how far it would be a right decision for both the countries in order to maintain their economic growth and nation security, it can be concluded that various parameters are indicating that both the countries are in need of military power, Economical and Industrial Growth both of them can fulfill their need by working with each other. Since the number of Chinese disputes of the border and Chinese occupation is increasing every year in both countries hence both are in need of maintaining the military and territorial security. In this way an increase in aid, Hydropower Aid diplomacy has become an essential need for both countries.

Though some of the impacts and challenges of the national security threat from china cannot be denied but by taking proper measures and by introducing the latest international support can be helpful for the both the countries. Similarly, political issues which occur during the India and Nepal relation like land acquisition, urban migration; poor health and sanitation problematic can be handled very efficiently by implementing and practicing governmental policies properly. More participation of both governments in the decision making process will help in fast and uninterrupted completion of Aid Projects.

\section{References}

[1] India-Nepal review projects under bilateral cooperation in Oversight Mechanism meeting https://theprint.in/diplomacy/india-nepal-reviewprojectsunderbilateral-cooperation-in-oversight-mechanismmeeting/483745/17/08/2020.

[2] DDP Secretariat, "Gandak Project", United Nations Environment Programme Dams and Development Project, http://www.unep.org/dams/documents/ell.asp?story_id=108.

[3] Embassy of India Kathmandu Nepal, “About India-Nepal Relations",

http://www.indianembassy.org.np/index1.php?option=e6r5wl VM8od_u8Y0CdwsDiTfg0cohLLpEcNS8hphu0\&id=uG6ODD6pDmyQZ2GVuAigr3dw3JsYiyXhalcKLgM4 KoQ. 
[4] Energypedia "Nepal Energy Situation", https://energypedia.info/wiki/Nepal_Energy_Situation, accessed on 21st April 2020, Hydro Consult Private Limited, "Environmental Impact Assessment (EIA) of Nyadi Hydropower Project", Nyadi Hydropower Project, 2011.

[5] Hydroelectricity Investment and Development Company Limited, "Nepal Hydropower Overview", Hydroelectricity Investment and Development Company Limited, http://www.hidcl.org.np/nepal-hydropower.php, accessed on 20 April 2020.

[6] Independent Power Producers' Association Nepal, Confederation of Indian Industry, "Nepal India Cooperation on Hydropower", SARI/e Small Grants Scheme, January 2006.Independent Power Producers' Association, Nepal, "Hydropower in Nepal"(http://www.ippan.org.np/HPinNepal.html).

[7] International Renewable Energy Agency, "Integrating lowtemperature renewables in district energy systems: Guidelines for policy makers (2021).

[8] Jha Hari Bansh,"Nepal- India Cooperation in River Water Management”, Strategic Analysis, vol. 37, no. 2, pp. 217-230.

[9] Jha Kalpana, "India-Nepal Power Agreements: Challenges before opportunities", Institute of Peace and Conflict Studies.

[10] http://www.ipcs.org/article/india/india-nepal-power-tradeagreement-challenges-before-opportunities-4854.html.
[11] Kumar Amrit, "Indo-Nepal Hydropower cooperation: The Way Forward”, Indian Council of World Affairs, 5 November 2014.

[12] Ministry of Power, Government of India, "Power Sector Glance ALL INDIA", Ministry of Power, Government of India, http://powermin.nic.in/power-sector-glance-all-india.

[13] SJVN Limited, “Arun III HEP”, SJVN Limited, http://sjvn.nic.in/project-details.htm?13.

[14] Subedi Bibek, "Potential Financers to meet IBN GMR Today, Upper Karnali Hydropower Project", The Kathmandu Post, http://kathmandupost.ekantipur.com/news/2016-0405/potential-financers-to-meet-ibn-gmr-today.html.

[15] Tabassum Shaista and Idris Nusrat,"India- Nepal Treaty on Mahakali River", Pakistan Institute of International Affairs, vol. 57, no. 2, 2004, pp. 51-61.

[16] US Energy Information Administration, "India is increasingly dependent on imported fossil fuels as demand continues to rise" http://www.eia.gov/todayinenergy/detail.cfm?id=17551.

[17] Water Resources Department, Government of Bihar, “Agreement between His Majesty's Government of Nepal and The Government of India on the Gandak Irrigation and Power Project", Water Resources Department, Government of Bihar, http://wrd.bih.nic.in/nepal59.htm.

[18] Cocks Franclin Hadley, Energy Demand and Climate Change Issues and Resolutions, Wiley-VCH GmbH \& Co. (2009) p. 102. 